\title{
Biometric relationships of the fat sleeper Dormitator maculatus (Bloch, 1792) (Teleostei: Eleotridae) from Alvarado lagoon, Veracruz, Mexico
}

\section{Relaciones biométricas del dormilón Dormitator maculatus (Bloch, 1972) (Teleostei: Eleotridae) de la Laguna de Alvarado, Veracruz, México}

Jonathan Franco-López 1

Luis Gerardo Abarca-Arenas 2 [0

Edgar Peláez-Rodríguez 1 [0]

José Luis Viveros-Legorreta!

Adrián Felipe González-Acosta ${ }^{3}$

${ }^{1}$ Laboratorio de Ecología. Facultad de Estudios Superiores Iztacala-UNAM, Av. De los Barrios 1, Col. Los Reyes Ixtacala, Tlalnepantla, CP. 54090 . Estado de México, México.

${ }^{2}$ Instituto de Investigaciones Biológicas, Universidad Veracruzana. Av. Luis Castelazo Ayala $\mathrm{s} / \mathrm{n}$ Col. Industrial Ánimas CP. 91190 Apartado Postal 294 Xalapa, Veracruz, México. ${ }^{3}$ Instituto Politécnico Nacional-Centro Interdisciplinario de Ciencias Marinas, Av. Instituto Politécnico Nacional $s / \mathrm{n}$, Col. Playa Palo de Santa Rita, CP. 23096. La Paz, Baja California Sur, México.

*Corresponding author: aacosta@ipn.mx

\section{Scientific note}

Received: July 14, 2020

Accepted: April 06, 2021

How to cite: Franco-López J, AbarcaArenas LG, Peláez-Rodríguez E, Viveros-Legorreta JL, GonzálezAcosta AF (2021) Biometric relationships of the fat sleeper Dormitator maculatus (Bloch, 1792) (Teleostei: Eleotridae) from Alvarado lagoon, Veracruz, Mexico. Ecosistemas y Recursos Agropecuarios 8(1): e2679. DOI: 10.19136/era.a8n1.2679
ABSTRACT. Length-weight and eight biometric relationships for Dormitator maculatus in the Alvarado lagoon were evaluated for 500 specimens (252 females and 248 males), $23.7-143.9 \mathrm{~cm}$ TL and $0.95-59.1 \mathrm{~g}$ weight, sampled during May 2015 to May 2017, using traditional fishing gears. The $b$ coefficient indicated isometric growth $\left(b=3.0195, r^{2}>0.9763, \mathrm{P}<\right.$ $0.05)$ for overall sample, females $\left(b=3.0507 ; r^{2}>0.989 ; \mathrm{P}<0.05\right)$ and males $\left(b=2.9953 ; r^{2}>0.9783 \mathrm{P}<0.05\right)$. Biometric relationships showed high correlation coefficients $\left(r^{2}>0.9193-0.9992, \mathrm{P}<0.05\right)$ for the overall sample, females $\left(r^{2}>0.9188-0.9981 ; \mathrm{P}<0.05\right)$ and males $\left(r^{2}>0.9079-\right.$ $0.9995, P<0.05)$. This study reports $L-W$ and biometric relationships for the fat sleeper, these results will be useful to delineate a baseline for regulations and the sustainable fishery management of this fish species.

Key words: Biometry, eleotrid fish, Gulf of Mexico, fish growth, LWR parameters, regression models.

RESUMEN. Se evaluaron las relaciones de Peso-Longitud y biométricas de D. maculatus en la Laguna de Alvarado, para un total de 500 ejemplares (252 hembras y 248 machos), $23.7-143.9 \mathrm{~cm}$ LT y $0.95-59.1 \mathrm{~g}$, recolectados en 10 localidades durante Mayo 2015 a Mayo 2017, utilizando artes de pesca tradicionales. El cálculo del coeficiente de correlación $b$ indicó crecimiento de tipo isométrico $\left(b=3.0195, r^{2}>0.9763, \mathrm{P}<0.05\right)$ para la muestra total, hembras $\left(b=3.0507, r^{2}>0.989, \mathrm{P}<0.05\right)$ y machos $\left(b=2.9953, r^{2}>0.9783 \mathrm{P}<0.05\right)$. Las relaciones biométricas mostraron relaciones significativas para la población total $\left(r^{2}>0.9193-0.9992, \mathrm{P}<\right.$ $0.05)$, hembras $\left(r^{2}>0.9188-0.9981, \mathrm{P}<0.05\right)$ y machos $\left(r^{2}>0.9079-\right.$ $0.9995, P<0.05)$. En este estudio se reporta información sobre las relaciones biométricas de la naca, estos resultados servirán de línea base para el planteamiento de regulaciones y un manejo sustentable de la pesquería de esta especie de pez.

Palabras clave: Biometría, eleótridos, Golfo de México, crecimiento, parámetros de la regresión $\mathrm{P}-\mathrm{L}$, modelos de regresión. 


\section{INTRODUCTION}

Alvarado lagoon (Mexico) is an estuarinecoastal ecosystem used by a variety of young and adult fish species as primary habitat or nursery grounds for feeding and spawn, making use of the available resources provided by this environment at different (seasonal) times (Franco-López et al. 1996, Cruz-Escalona et al. 2018). One of these fish species is the fat sleeper (locally named "naca") Dormitator maculatus (Blotch, 1792), an euryhaline fish species that commonly lives in fresh and salt waters of spring lagoons, muddy ponds, marshes, mangrove swamps and tidal pools in estuaries and coastal lagoons along the Western Atlantic coast, from New York (USA), including the Bahamas and Gulf of Mexico to southeastern Brazil (Nordlie and Haney 1993, Nordlie 2000, McEachran and Fechhelm 2005, Miller et al. 2005).

Fat sleepers regularly enter to Alvarado lagoon biotopes to feeding and spawn during the months of September to December, when local fishermen take advantage of the abundant presence of populations of this species, catching them almost to overexploitation due to the high demand and price that the female gonads reach in the local markets (Franco-López et al. 1996, 2020, Dávila-Camacho and Galaviz-Villa 2020). Ecologically, D. maculatus perform an important contribution to the structure and dynamic of the Alvarado lagoon food web, participating as an omnivorous consumer (primary and secondary), likewise as a prey of another fish species, birds, turtles and aquatic mammals (Nordlie 1981, Berra 2001, Jonna and Weinheimer 2003, Franco-López et al. 2020). Thus, the fat slepeer like other estuarine fish species could represent critical links in the food chains, between estuarine-lagoon biotopes and the adjacent coastal and marine ecosystems (Oberrecht 2014, González-Acosta et al. 2015).

Despite its commercial value and ecological importance, few studies have been conducted to the biological knowledge of the fat sleeper (Froese and Pauly 2021); some of them address eggs and larvae description (Flores-Coto and Zavala 1982), their ecological niche, feeding, reproduction and growth
(Nordlie1981, 2000, Franco-López et al. 2020), environmental adaptation (Nordlie and Haney 1993), parasites (Montoya et al. 2004) and phylogenetic relationships (Galván-Quesada et al. 2016). Therefore, this study reports the LWR and eight biometric relationships: standard length [SL]-weight [LWR] and standard length-total length [SL-TL], SL-depth body [DB], DB-head length [HL] and mouth length-eye diameter [ML-ED] for $D$. maculatus; these results will be useful to delineate a baseline for regulations and the sustainable fishery management of this species in the Alvarado estuarine lagoon ecosystem.

\section{MATERIALS AND METHODS}

A total of 500 specimens (252 females and 248 males) of fat sleepers were sampled during May 2015 to May 2017 covering dry, rainy and windy seasons, in ten localities of the Alvarado lagoon (Figure 1), characterized by the presence of submerged vegetation over mud bottoms. A seine net $50 \mathrm{~m}$ length, $2.5 \mathrm{~m}$ high and $2.5 \mathrm{~cm}$ mesh size, was used for the caught of fish specimens, which were preserved in formalin $10 \%$ to be moved to the Laboratorio de Ecología of the Facultad de Estudios Superiores Iztacala-UNAM. The specimens were identified using the taxonomic keys of Castro-Aguirre et al. (1999) and McEachran and Fechhelm (2005).

All specimens were measured at their standard $(\mathrm{SL})$ and total length (TL) as well as in other biometric characters: head $[\mathrm{HL}]$ and mouth length [ML], body depth [BD] and eye diameter [ED], using a fish measuring board $(0.1 \mathrm{~mm})$ and weighed using a digital scale $(0.1 \mathrm{~g})$. The sex of each specimen was determined through macroscopic observation of the gonads.

Length-weight relationship (LWR) was calculated using equation expressed as: $\mathrm{W}=a \mathrm{TL}^{b}$ (Le Cren 1951, Bagenal and Tesch 1978), were $W=$ weight $(\mathrm{g})$ and $\mathrm{TL}=$ Total length $(\mathrm{cm})$, separately for females and males by transforming $\mathrm{W}$ and $\mathrm{TL}$ data to logarithmic values and fitting them to linear equation: $\mathrm{W}=\log a+b \log \mathrm{TL}$, using least squares method with $a$ as the interception between the regression line and the $y$-axis, and $b$ the slope of the 


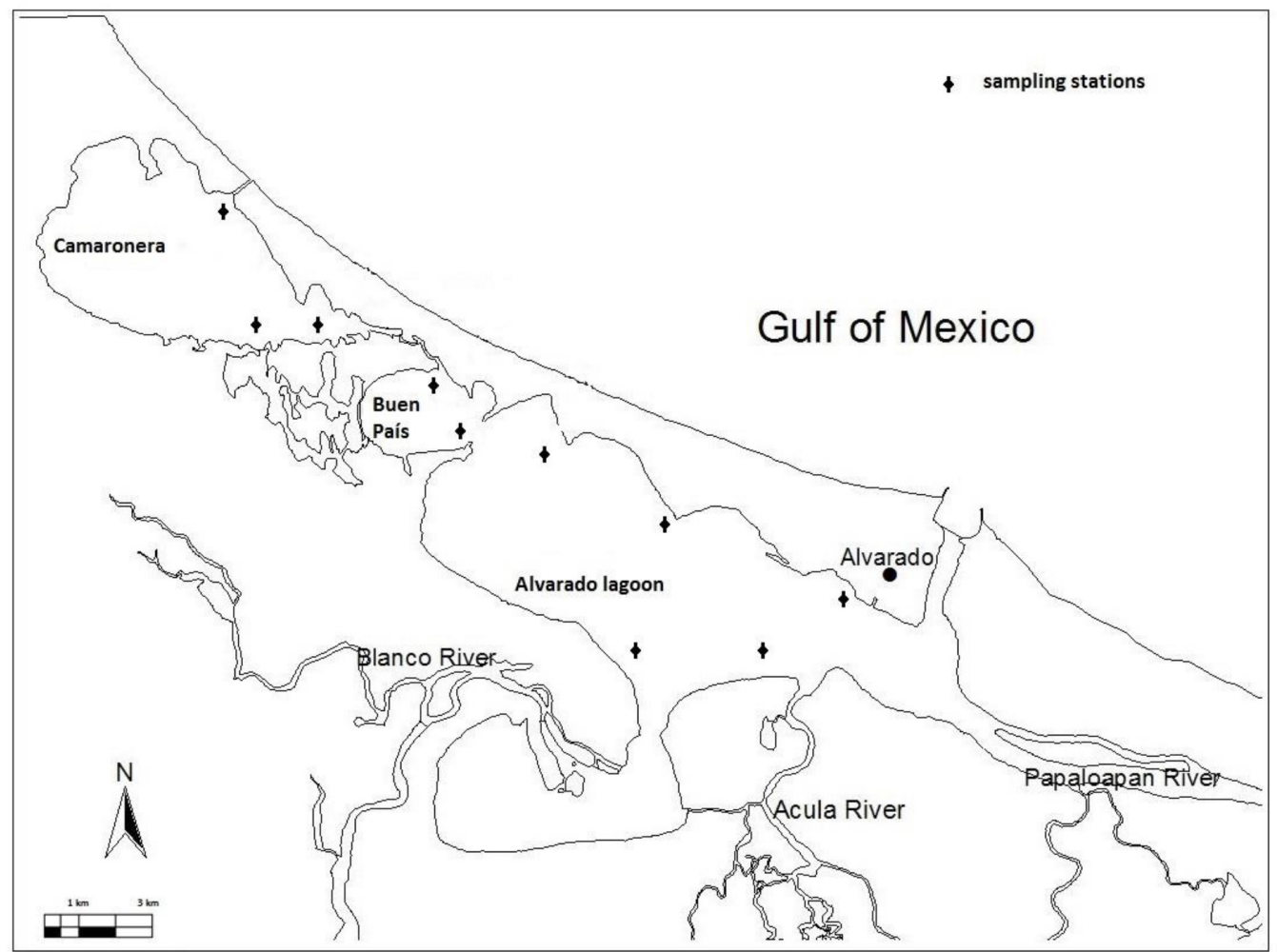

Figure 1. Sample locations in the Alvarado lagoon estuarine coastal system, Veracruz, Mexico.

regression line (López-Fuerte et al. 2016). In accordance with Froese et al. (2011), extreme data values were eliminated based on the analysis by graphing log-transformed length and weigh data. To assess whether the LWR $b$-values differs from those of indicative isometric growth $(b=3.0)$, a student's t-test was conducted (Zar, 2010). In addition, TL-SL and biometric relationship were analyzed by simple linear regression ( $\mathrm{TL}$ or $\mathrm{Y}=a+b \mathrm{SL}$ or $\mathrm{X}$ ). The statistical significance level $\left(r^{2}\right)$ was estimated and used as indicator of the quality of the linear regressions (Bolger and Connolly 1989).

\section{RESULTS AND DISCUSSION}

A total of 500 specimens of $D$. maculatus (23.7 - $143.9 \mathrm{~mm}$ TL, 19.3 -114.4 mm SL and 0.95 - 59.1 $\mathrm{g}$ weight) were caught through this study; the overall sample showed a significant positive power function between TL and W $\left(r^{2}=0.9763\right)$, and between TL and
$\mathrm{SL}\left(\mathrm{TL}=0.6509+0.7778 \mathrm{SL} ; r^{2}=0.9992\right)$. Female fat sleepers (23.7 - $143.9 \mathrm{~mm}$ TL and $20.6-114.7$ $\mathrm{mm} \mathrm{SL}, 1.02$ - $59.13 \mathrm{~g}$ weight) comprised $50.4 \%$ of the total sample and displayed a robust positive power function between TL and $\mathrm{W}\left(r^{2}=0.989\right)$, and between TL and SL (TL = $1.0437+0.7772 \mathrm{SL} ; r^{2}=$ 0.9981). Male fat sleepers (24.2 - $141.8 \mathrm{~mm} \mathrm{TL}$ and 19.5 - $110.3 \mathrm{~mm} \mathrm{SL} ; 0.95$ - $58.63 \mathrm{~g}$ weight) comprised $49.68 \%$ of the overall sample; males group showed a significant positive power function between TL and W $\left(r^{2}=0.9783\right)$ and between $\mathrm{TL}$ and $\mathrm{SL}(\mathrm{TL}=0.252+$ $\left.0.7785 \mathrm{SL} ; r^{2}=0.9995\right)$.

Regression analyses describing the relation of $\mathrm{TL}$ and $\mathrm{W}$ derived $a b$ value statistically equal to 3.0 for females $(b=3.0507$ : t-test, $\mathrm{P}<0.05)$, males $(b=$ 2.995 , t-test, $\mathrm{P}>0.05)$ and overall fish sample $(b=$ 3.0195, $t$-test, $\mathrm{P}>0.05$ ), indicating isometric growth (Table 1). Moreover, the biometric relationships presented in table 2 were highly significant $(P<0.05)$ with all coefficients of determination values being $>$ 0.9079; showing isometric growth for all cases. 
Table 1. Length-weight and standar length-total length parameters of the fat sleeper Dormitator maculatus, in the Alvarado lagoon estuarine coastal system.

\begin{tabular}{|c|c|c|c|c|c|c|c|c|c|c|c|c|}
\hline Sex & $\mathrm{N}$ & $\begin{array}{c}\text { TL range } \\
(\mathrm{mm})\end{array}$ & $\begin{array}{l}\text { W range } \\
(\mathrm{g})\end{array}$ & $a$ & SE $a$ & $\begin{array}{c}95 \% \text { IC } \\
\text { of } a\end{array}$ & $b$ & SE $b$ & $\begin{array}{c}95 \% \text { IC } \\
\text { of } b\end{array}$ & $r^{2}$ & Ts & Growth type \\
\hline Females & 252 & $23.7-143.9$ & $1.02-59.13$ & $1.619^{-5}$ & 0.0394 & $1.6119^{-5}-0.0773$ & 3.0507 & 0.0428 & $3.0507-0.038$ & 0.989 & 1.18292 & 1 \\
\hline Males & 248 & $24.2-141.8$ & $0.95-58.63$ & $2.199^{-5}$ & 0.0599 & $2.199^{-5}-0.1175$ & 2.995 & 0.0529 & $2.995-0.0594$ & 0.9783 & -0.0941 & 1 \\
\hline Pooled & 500 & $23.7-143.9$ & $0.95-59.1$ & $3.734^{-5}$ & 0.0419 & $3.0195-0.0139$ & 3.0195 & 0.0712 & $3.7347^{-5}-0.0821$ & 0.9763 & 0.2735 & I \\
\hline
\end{tabular}

Table 2. Biometric relationships for the fat sleeper in the Alvarado lagoon estuarine coastal system.

\begin{tabular}{lccccccc}
\hline Sex & $\mathrm{n}$ & Equation & $\mathrm{a}$ & $95 \% \mathrm{Cl}$ of $\mathrm{a}$ & $\mathrm{b}$ & $95 \% \mathrm{Cl}$ of $\mathrm{b}$ & $r^{2}$ \\
\hline Females & 252 & $\mathrm{TL}=\mathrm{a}+\mathrm{b} \mathrm{SL}$ & 1.0437 & $1.0437-4.0025$ & 0.7772 & $0.7785-0.041$ & 0.9981 \\
& 252 & $\mathrm{TL}=\mathrm{a}+\mathrm{b} \mathrm{DB}$ & 4.3725 & $4.3725-7.3189$ & 0.2293 & $0.2293-0.0075$ & 0.9351 \\
& 252 & $\mathrm{SL}=\mathrm{a}+\mathrm{b} \mathrm{DB}$ & 4.2652 & $4.2625-8.2849$ & 0.2922 & $0.2922-0.1078$ & 0.9188 \\
& 252 & $\mathrm{SL}=\mathrm{a}+\mathrm{b} \mathrm{HL}$ & 3.0619 & $3.0619-1.690$ & 0.2744 & $0.2744-0.0219$ & 0.9958 \\
& 252 & $\mathrm{HL}=\mathrm{a}+\mathrm{b} \mathrm{ML}$ & -0.3191 & $-0.3191-0.8952$ & 0.3522 & $0.3523-0.0374$ & 0.9927 \\
Males & 252 & $\mathrm{HL}=\mathrm{a}+\mathrm{b} \mathrm{ED}$ & -0.1928 & $-0.1928-0.7479$ & 0.3067 & $0.3067-0.0312$ & 0.9933 \\
& 248 & $\mathrm{TL}=\mathrm{a}+\mathrm{b} \mathrm{SL}$ & 0.2520 & $0.2520-1.9112$ & 0.7785 & $0.7785-0.0199$ & 0.9995 \\
& 252 & $\mathrm{TL}=\mathrm{a}+\mathrm{b} \mathrm{DB}$ & 4.8178 & $4.8178-7.4184$ & 0.2051 & $0.2051-0.0773$ & 0.9156 \\
& 252 & $\mathrm{SL}=\mathrm{a}+\mathrm{b} \mathrm{DB}$ & 4.8308 & $4.8308-7.7702$ & 0.2622 & $0.2922-0.1078$ & 0.9079 \\
& 252 & $\mathrm{SL}=\mathrm{a}+\mathrm{b} \mathrm{HL}$ & 3.2572 & $3.2572-1.6392$ & 0.2699 & $0.2699-0.0218$ & 0.9957 \\
& 252 & $\mathrm{HL}=\mathrm{a}+\mathrm{b} \mathrm{ML}$ & -0.3530 & $-0.3530-0.8366$ & 0.3523 & $0.3523-0.0359$ & 0.9932 \\
Pooled & 252 & $\mathrm{HL}=\mathrm{a}+\mathrm{b} \mathrm{ED}$ & -0.1715 & $-0.1715-1.4179$ & 0.2983 & $0.2983-0.0609$ & 0.9736 \\
& 500 & $\mathrm{TL}=\mathrm{a}+\mathrm{b} \mathrm{SL}$ & 0.6509 & $0.6569-2.5244$ & 0.7778 & $0.7778-0.0260$ & 0.9992 \\
& 500 & $\mathrm{TL}=\mathrm{a}+\mathrm{b} \mathrm{DB}$ & 4.5931 & $4.5931-7.2102$ & 0.2173 & $0.2173-0.0745$ & 0.9292 \\
& 500 & $\mathrm{SL}=\mathrm{a}+\mathrm{b} \mathrm{DB}$ & 4.5211 & $4.5211-7.7526$ & 0.2778 & $0.2778-0.1021$ & 0.9193 \\
& 500 & $\mathrm{SL}=\mathrm{a}+\mathrm{b} \mathrm{HL}$ & 3.1403 & $3.1403-1.0333$ & 0.2725 & $0.2725-0.0136$ & 0.9983 \\
& 500 & $\mathrm{HL}=\mathrm{a}+\mathrm{b} \mathrm{ML}$ & -0.3475 & $-0.3475-0.7462$ & 0.3528 & $0.3528-0.0316$ & 0.9948 \\
& 500 & $\mathrm{HL}=\mathrm{a}+\mathrm{b} \mathrm{ED}$ & -0.1954 & $-0.1954-0.9252$ & 0.3031 & $0.3031-0.0392$ & 0.9892 \\
\hline
\end{tabular}

According to our knowledge, no information dealing on the length (L) - weight (W) and biometric relationships for $D$. maculatus are available in the literature (e. g. Froese and Pauly 2021). Considering that currently the population size of the fat sleeper is decreasing due to overfishing in the Alvarado lagoon (Franco-López et al. 2020, Dávila-Camacho and Galaviz-Villa 2020); thus, the estimation of LWRs parameters $(a$ and $b$ ) are necessary for fishery management purposes of this species.

Through LWRs information it will be possible to study ontogenetic changes as well as other aspects of fish population dynamics like growth rates, age structure and condition index (Quist et al. 2012, SandovalHuerta et al. 2015); this is important to study aspects of the reproductive biology of $D$. maculatus which reach sexual maturity earlier at the beginning of their second year of life, and because its normal longevity is two or three years (Nordlie 2000).

All allometric coefficients $(b)$ estimated in this study were within the expected range of 1.96 and 3.94 (Froese 2006), since the fat sleeper specimens were caught over different periods and locations, $a$ and $b$ parameters represent mean annual values; which range between those of 2.73 (females) and 3.09 to 3.35 (males) reported for its congener the Pacific fat sleeper D. latifrons (Richardson 1844) in the Central Mexican Pacific, varying in the type of growth from isometric (Rojas-Herrera et al. 2009) to allometric (Sandoval-Huerta et al. 2015).

In general, $b$ values for females, males and overall sample statistically were not different from 3.0, indicating isometric growth for all cases; that is, the fish grows equal in length than in weight (Karachle and Stergiou 2012). This kind of growth reported here differs from the allometric growth reported by DávilaCamacho and Galaviz-Villa (2020) for both sexes of $D$. maculatus in the Alvarado lagoon; such differences could be due to the sample size as well as the size frequency of the assessed specimens in both studies

To our best knowledge, this study presents for the first time basic information on eight biometric relationships for $D$. maculatus, which in all cases indicating isometric growth (all morphometric measures 
growth increases in the same proportion). Although no information on biometric relationships currently exists in the literature (e. g. Froese and Pauly 2021) and consequently there are not point of comparison. Our results will contribute to improve the knowledge and conservation of the fat sleeper $D$. maculatus throughout its distribution area, as well as to delineate a baseline for regulations and the sustainable fishery management of the fat sleeper in the estuarine ecosystem of Alvarado lagoon.

\section{ACKNOWLEDGEMENTS}

This study was partially supported by the División de Investigación from the FES-Iztacala, UNAM. We thank to anonymous reviewers who contributed to improve this manuscript. This contribution is in memoriam of Charly Bedia who contributed in obtaining the data here presented. AFGA thanks the grants from EDI and COFAA-IPN, and SNI-CONACyT Programs, and the partial support of the SIP-IPN 20200034 and 20210558 projects

\section{LITERATURE CITED}

Berra T (2001) Freshwater Fish Distribution. Academic Press, San Diego, California. USA. 604p.

Bagenal TB, Tesch FW (1978) Age and growth. In: Bagenal T (ed.), Methods for assessment of fish production in fresh waters. 3rd edition IBP Handbook No. 3. Blackwell Science Publication. Oxford, USA. pp: 101-136.

Bolger T, Connolly PL (1989) The selection of suitable indices for the measurement and analysis of fish condition. Journal of Fish Biology 34: 71-182.

Castro-Aguirre JL, Espinosa-Pérez HS, Schmitter-Soto JJ (1999) Ictiofauna estuarino-lagunar y vicaria de México. Instituto Politécnico Nacional-Limusa, Distrito Federal, México. 711p.

Cruz-Escalona VH, Morales-Zárate MV, Franco-López J, Abitia-Cárdenas LA, Hernández-López A, Marín-Enríquez E, González-Acosta AF (2018) Food-web structure and functioning of coastal marine ecosystems: Alvarado Lagoon and adjacent continental shelf, Northern Gulf of Mexico. The Open Fish Science Journal 2018: 73-94.

Dávila-Camacho CA, Galaviz-Villa I (2020) Basic biological aspects of Dormitator maculatus "Naca”(Bloch, 1792) from the Alvarado Lagoon in Veracruz, Mexico. IOP Conference Series: Earth and Environmental Science 690 (2021): 012063. DOI: 10.1088/1755-1315/690/1/012063.

Flores-Coto C, Zavala GF (1982) Descripción de huevos y larvas de Dormitator maculatus (Bloch) de la Laguna de Alvarado, Veracruz (Pisces: Gobiidae). Anales del Instituto de Ciencias del Mar y Limnología 9: 127-140.

Franco-López J, Chávez-López R, Peláez-Rodríguez E, Bedia-Sánchez C (1996) Riqueza ictiofaunística del Sistema Lagunar de Alvarado, Veracruz. Revista de Zoología 2: 17-32.

Franco-López J, Bedia-Sánchez CM, Peláez-Rodríguez E, Viveros-Legorreta JL, Ortiz-Touzet MA, VázquezLópez H (2020) Ecological aspects of Dormitator maculatus Bloch, 1792 in the Alvarado Lagoon, Veracruz, Mexico. Turkish Journal of Fisheries \& Aquatic Sciences 20: 51-60.

Froese R (2006) Cube law, condition factor and weight-length relationships: history, meta-analysis and recommendations. Journal of Applied Ichthyology 22: 241-253.

Froese R, Pauly D (eds.) (2021) FishBase. Version 12/2020. http://www.fishbase.org. Data consulted: february 26, 2021.

Froese R, Tsikliras AC, Stergiou KI (2011) Editorial note on weight-length relations of fishes. Acta Ichthyologica et Piscatoria 41: 261-263. 
Galván-Quesada S, Doadrio I, Alda F, Perdices A, Reina RG, García-Varela M, Hernández N, Campos-Mendoza A, Bermingham E, Domínguez-Domínguez O (2016) Molecular phylogeny and biogeography of the amphidromous fish genus Dormitator Gill, 1861 (Teleostei: Eleotridae). PLoSONE 1(14): e0153538. DOI: 10.1371/journal.pone.0153538

González-Acosta AF, Ruiz-Campos G, Balart EF (2015) Composition and zoogeography of fishes in mangrove ecosystems of Baja California Sur, México. In: Riosmena-Rodriguez R, González-Acosta AF, Muñiz-Salazar $\mathrm{R}$ (eds.) The arid mangroves from Baja California Peninsula. Volume 1. Nova Science Publishers, Inc., Hauppauge, New York. pp: 63-80.

Jonna R, Weinheimer M (2003) Eleotridae. Animal Diversity Web. http://animaldiversity.ummz.umich.edu/site/ accounts/information/Eleotridae.html. Data consulted: February 26, 2021.

Karachle PK, Stergiou K (2012) Morphometrics and allometry in fishes. In: Whal C (ed.) Morphometrics. InTech. Rijeka, Croatia. pp. 65-86.

Le Cren ED (1951) The length-weight relationship and seasonal cycle in gonad weight and condition in perch (Perca flavescens). Journal of Animal Ecology 20: 201-219.

López-Fuerte O, Jakes-Cota U, González-Acosta AF, Flores-Ramírez S (2016) Length-weight and length-length relationships, and condition factor of the pelican barracuda Sphyraena idiastes Heller and Snodgrass, 1903 (Perciformes: Sphyraenidae) in the Gulf of California, Mexico. California Fish and Game 102: 183-187.

McEachran JD, Fechhelm JD (2005) Fishes of the Gulf of Mexico. Vol. 2 Scorpaeniformes to Tetraodontiformes. University of Texas Press. Austin, Texas. USA. 1114p.

Miller RR, Minckley WL, Norris SM (2005) Freshwater fishes of Mexico. The University of Chicago Press, Chicago, Illinois. USA. 490.

Montoya MJ, Osorio SD, Chávez-López R, Franco-López J (2004) Helmintos del pez Dormitator maculatus (Osteichthyes: Eleotridae) de Alvarado, Veracruz México. Revista de Biología Tropical 52: 393-396.

Nordlie FG (1981) Feeding and reproductive biology of eleotrid fishes in a tropical estuary. Journal of Fish Biology 18: $97-110$.

Nordlie FG (2000) Patterns of reproduction and development of selected resident teleosts of Florida salt marshes. Hydrobiologia 434: 165-182.

Nordlie FG, Haney DC (1993) Euryhaline adaptations in the fat sleeper, Dormitator maculatus. Journal of Fish Biology 43: 433-439. doi:

Oberretch K (2014) Estuaries as nurseries. www.oregon.gov/DSL/ssnerr/.../efs08estnurse.pdf/. Data consulted: March 04, 2019.

Quist MC, Pegg MA, Devires DR (2012) Age and growth. In: Alexander AV, Parrish DL, Sutton TM (eds.) Fisheries techniques. American Fisheries Society, Bethesda, MD. pp: 677-631.

Rojas-Herrera AA, Violante-González J, Palacios-Salgado D (2009) Length-weight relationships and seasonality in reproduction of six commercially utilized fish species in the coastal lagoon of Tres Palos (Mexico). Journal of Applied Ichthyology 25: 234-235.

Sandoval-Huerta ER, Madrigal-Guridi X, Domínguez-Domínguez O, Ruiz-Campos G, González-Acosta AF (2015) Length-weight and length-length relations for 14 fish species from the central Mexican Pacific coast. Acta Ichthyologica et Piscatoria 45: 199-201.

Zar JH (2010) Biostatistical Analysis. Prentice Hall. New Jersey, USA. 944p. 